\title{
PENETAPAN SUSUNAN AYAT, SURAT DAN RASM AL-QUR'AN
}

\author{
Yulia Rahmi \\ IAIN Bukittinggi \\ yuliabkt@gmail.com
}

\begin{abstract}
Abstrak, Penetapan Susunan Ayat, Surat dan Rasm al-Qur'an. Kodifikasi alQur'an pada masa Usman bin Affan melahirkan Mushaf Usmani sebagai hasilnya. Setelah berlalunya masa kodifikasi, muncul perbincangan hangat tentang susunan atau tertib ayat dan surat yang ada dalam al-Qur'an karena pada mushaf yang disusun oleh Usman dan timnya ditemukan perbedaan dengan susunan ayat dan surat yang ada pada mushaf-mushaf para shahabat lainnya. Para ulama sepakat tentang tauqifiynya susunan ayat-ayat al-Qur'an (sesuai dengan yang ditetapkan oleh Nabi). Begitu pula halnya dengan susunan surat-surat dalam al-Qur'an dipahami sebagai sesuatu yang bersifat tauqifiy dari nabi, walaupun para ulama terdapat perbedaan pendapat namun argumen atau dalil tauqifiynya susunan surat lebih kuat dibandingkan 2 argumen lainnya yang berpendapat bahwa susunan surat-surat adalah ijtihadiy seluruhnya atau pun pendapat yang menyatakan sebagiannya ijtihadiy dan sebagiannya tauqifiy. Pembicaraan lain yang muncul adalah tentang rasmi al-Qur'an pada mushaf Usman. Argumen dan dalil yang dikemukakan menunjukkan bahwa rasm al-Qur'an adalah istilah untuk pola penulisan al-Qur'an yang disepakati oleh Usman bukan tauqifiy daru Nabi, mengikutinya tidak wajib namun demikian rasm Usman tetap harus dijadikan standarisai pola penulisan al-Qur'an.
\end{abstract}

\section{Kata Kunci : Tauqifiy, Ijtihadiy, Ishthilahiy, Rasm Usman}

Abstract, The Sequence of Verses, Surahs and Rasm of Quran. Codification of Quran during the Utsman caliphate produced Usmani manuscripts (mushaf). After the codification era, the controversy about the sequence of verses and surah in the Quran appeared, because the manuscripts compiled by Usman and his team were found to be different with manuscripts sequence from other Companions. The scholars agreed on the tauqifiy of verses sequence in the Quran in which should be as determined by the Prophet. Likewise, the sequence of verses in the Quran was believable as something that is tauqifiy of the prophet. Although among the scholars there were a different opinion, but the argument on its tauqifiy of surah squence was stronger than two other arguments that defined, it was ijtihadiy entirely, or opinion stated to apply ijtihadiy and tauqifiy partly. Another controversy that arose, was about the the rasm of Quran in Usmani Manuscripts. The arguments that were presented indicated that rasm of Quran was the term for the Quran's writing pattern agreed by Usman not tauqifiy of the Prophet. Following this pattern is not obligation, but the rasm of Utsman must keep to be Standardization pattern in writing the Quran.

Keywords: Tauqifiy, Ijtihadiy, Ishthilahiy, Rasm Usman 
186 JURNAL ULUNNUHA, Volume 6, Nomor 2, Desember 2017, hlm.185-196

\section{PENDAHULUAN}

Secara dogmatis umat Islam meyakini bahwa al-Qur'an merupakan sumber ajaran agama yang utama, yang merupakan Kalamullah sekaligus berfungsi sebagai mukjizat dan bukti keRasulan Muhammad.

Al-Qur'an pada periode Rasulullah Saw, belum terkodifikasi namun masih dalam bentuk manuskrip yang tersebar di berbagai media. Usaha pengumpulan al-Qur'an dilaksanakan pada masa pemerintahan Khalifah Abu Bakar Shiddiq, atas inisiatif Umar bin Khathab. Sedangkan kodifikasi alQur'an terlaksana pada masa pemerintahan Usman bin Affan, yang pada akhirnya al-qur'an yang telah dikodifikasi dikenal dengan nama Mushhaf Usmaniy.

Pada mushhaf Usmaniy susunan ayat dan surat al-Qur' an disusun berbeda dengan kronologis turun ayat al-Qur'an. Hal ini menjadi suatu polemik yang memunculkan perbedaan dalam memahami tertib ayat dan surat yang ada dalam al-Qur'an. Bahkan juga memunculkan perbedaan dalam pola penulisan (rasm) al-Qur'an.

\section{SUSUNAN AYAT}

Ayat merupakan bagian dari alQur'an yang secara etimologi dapat berarti : المعجزة , العبرة, العلامة, (Abu Luwis Ma'luf, $1986: 22$ )

Secara terminology, sebagaimana yang dijelaskan oleh Manna' Khalil al-Qathan, bahwa ayat adalah :
الجملة من كلام الله المندرجة في سورة القرآن

(Manna' Khalil al-Qathan, 1983 : 139)

"Susunan kata dari kalamullah yang terdapat dalam sebuah surat dar: $\sim$ Qur'an"

Senada dengan definisi tersebut, az-Zarqaniy menambahkan bahwa ayat adalah :

طائفة ذات مطلع و مقطع مندرجة في سورة من القرآن (339 : az-Zarqaniy, 1990

"Sekelompok kata yang mempunyai awal dan akhir yang termasuk dalam suatu surat al-Qur'an"

Beranjak dari definisi yang dikemukakan, dapat dipahami bahwa ayat merupakan bagian dari surat yang ada dalam al-Qur'an, terdiri dari sejumlah huruf yang memiliki batas permulaan dan penutup.

Ketika membahas susunan dan urutan ayat-ayat al-Qur'an, para ulama sepakat bahwa susunan ayat yang terdapat pada mushahf sekarang ini adalah tauqify ${ }^{l}$ nabi Muhammad (as-Suyuthi, 1979 : 62).

Kesepakatan ini berdasarkan kepada beberapa riwayat yang menunjukkan penetapan nabi tentang urutan / susunan dari ayat al-Qur'an, antara lain

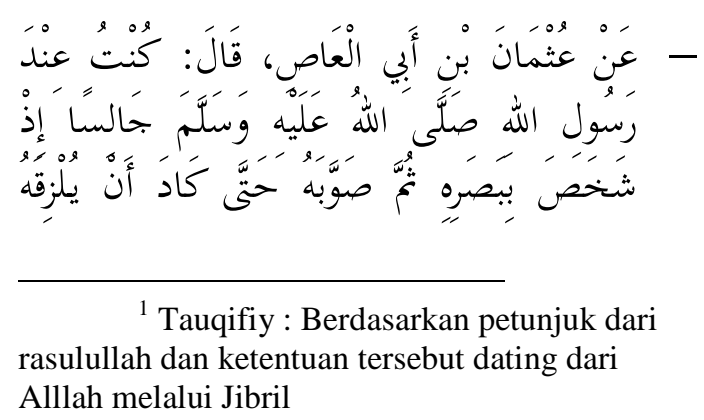
rasulullah dan ketentuan tersebut dating dari Alllah melalui Jibril 


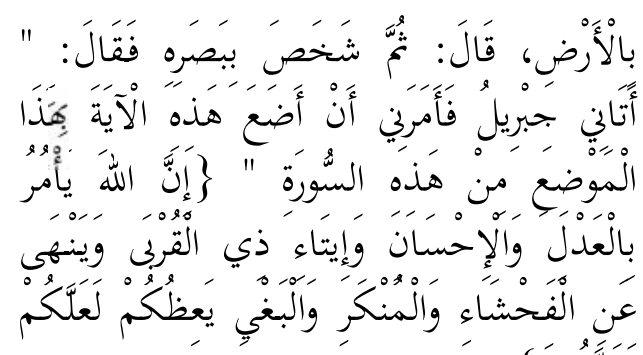

( Mَذَخَرُونَ : no.17918)

Dari Usman bin Abi al-ash, ia berkata: "Aku sedang duduk di smaping Rasulullah, tiba-tiba pandangannya mnejadi tajam lalu kembali seperti semula, kemudian beliau bersabda : Jibrail telah dating kepadaku dan memerintahkan agar aku meletakkan ayat ini dari surat in

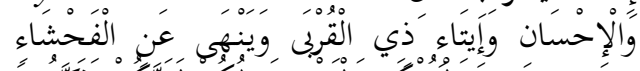

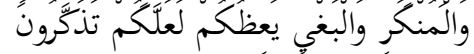

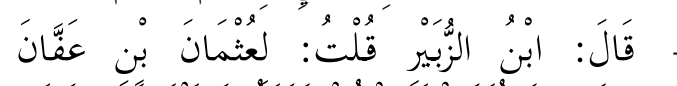

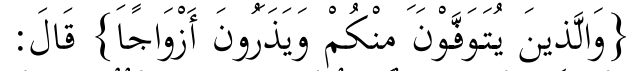

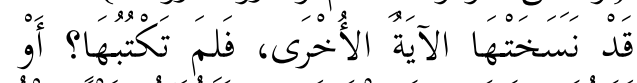

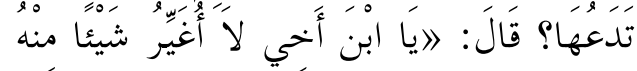

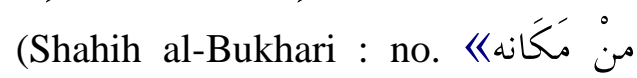
4530)

Ibnu Zubair berkata : Aku bertanya kepada Usman tentang ayat ini وَّنَ

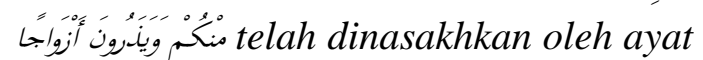
yang lain, tetapi mengapa engkau masih menulisnya? atau membiarkannya?, ia menjawab : Keponakanku aku tidak mengubah sesuatu pun dari tempatnya.

Riwayat-riwayat tersebut menjadi isyarat bahwa susunan ayat-ayat alQur'an adalah tauqifiy dari nabi sesuai dengan petunjuk dari Allah. Sehingga Usman tetap memasukkan ayat-ayat yang telah dinasakhkan hukumnya dalam susunan ayat-ayat al-Qur'an karena hal ini telah menjadi ketetapan dari Nabi.

Indikasi lain yang menjelaskan susunan dan urutan ayat itu bersifat tauqifiy adalah bacaan nabi ketika shalat yang mengurutkan susunan ayat-ayat alQur'an dalam membacanya, atau pun ketika beliau berkhutbah Jum'at, sebagaimana hadis-hadis shahih tentang bacaan Nabi Saw terhadap sejumlah surat sebagaimana surat al-Baqarah, Ali Imran dan An-Nisak (az-Zarqaniy : 347)

Nabi Muhammad selalu mengulangi hafalannya dihadapan Jibril pada setiap tahunnya, dan pada tahun terakhir sebelum wafatnya Nabi sempat dua kali mengulangi hafalannya. (AzZarqaniy : 346) Hal ini juga menjadi bukti bahwa susunan ayat adalah tauqifiy Nabi. Berdasarkan susunan ini pulalah yang diajarkan Nabi kepada para shahabat, sehingga susunan ayat yang ada sekarang ini bebas dari ijtihad shahabat.

\section{SUSUNAN SURAT}

Kata surat secara etimologi beالمنزلة dengan makna dari kata السور (posisi) (Abu Luwis Ma'luf : 362), surat dari al-Qur'an telah dikenal, karena posisinya pada suatu tempat secara berdampingan.

Secara terminology, definisi surat sebagaimana yang dikemukakan oleh azZarqaniy adalah :

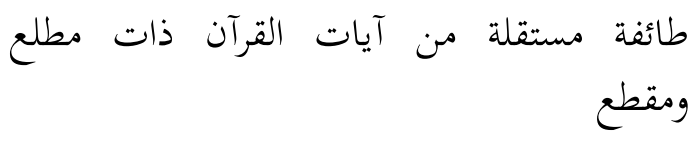


188 JURNAL ULUNNUHA, Volume 6, Nomor 2, Desember 2017, hlm.185-196

"Sekelompok (ayat) yang berdiri sendiri yang memiliki permulaan dan penutup". Qathan :

Menurut Manna' Khalil alآلجملة من آيات القرآن ذات المطلع و اقلها ثلاث آيات

"sejumlah ayat-ayat al-Qur'an yang mempunyai permulaan dan akhir, minimal terdiri dari 3 ayat"

Sedangkan az-Zarkasyi mendefinisikan surat sebagai berikut :

$$
\text { ثرآن يشتمل على آي ذوات فاتحة و خاتمة و اقلها }
$$

"Bacaan yang mencakup ayat-ayat yang memiliki awal pembukaan dan penutup minimal terdiri dari 3 ayat.

Berdasarkan definisi-definisi yang dikemukakan oleh para ulama tersebut dapat dipahami bahwa surat adalah sekumpulan ayat yang menimal terdiri dari 3 ayat yang memiliki permulaan dan akhir.

Sebagian ulama cenderung menetapkan bahwa nama-nama surat dalam al-Qur'an sebagiannya telah ditetapkan oleh Nabi Muhammad, dan sebagiannya diberikan oleh para shahabat. Nama-nama surat yang tidak merupakan ketetapan nabi pada umumnya adalah surat-surat yang memiliki lebih dari satu nama (Hasanuddin AF, 1995 : 74), antara lain :

1. Al-Fatihah, dinamakan juga dengan Ummu al-Qur'an, Sab'u al-Matsani, al-Kafiyat.

2. Al-Maidah, dinamakan juga dengan al-'Uqud, al Munqizat.
3. An-Naml, dinamakan juga dengan Sulaiman.

4. At-Taubah, dinamakan juga dengan al-Bara'ah.

Penamaan surat tersebut dilatarbelakangi oleh beberapa hal, antara lain :

1. Kandungan atau kisah yang paling menonjol pada surat tersebut.

2. Keistimewaan dari makhluk yang dijadikan nama surat, yang terdapat 'ibrah dari pembuatan makhluk tersebut.

3. Tema sentral yang ada pada surat tersebut.

4. Permulaan ayat dari surat, yang biasanya terdiri dari huruf muqaththa'ah.

Para ulama mengklasifikasikan surat-surat dalam al-Qur'an kepada beberapa kategori :

1. السبع الطوال atau tujuh surat yang panjang-panjang, terdiri dari : al-Baqarah, Ali Imran, AnNisak, Al-Maidah, al-an'am, al-A'raf dan Yunus.

2. المئون yaitu surat-surat al_qur'an yang terdiri dari 100 ayat atau lebih, seperti surat an-Nahl, Hud dan Yusuf.

3. المثنانى yaitu surat-surat yang kurang dari 100 ayat, seperti al-Ahzab, alHajj, al-Qashash.

4. المفصل yaitu surat-surat pendek yang terdapat pada susunan akhir alQur'an. Bagian ini dibagi kepada 3 kelompok :

a. طوال المفصل mulai dari surat alHujurat sam pai surat al-Buruj.

b. واسط المفصل, mulai dari surat athThariq sampai surat al-Bayyinah. 
c. قصار المفصل, mulai dari surat alZilzalah sampai surat an-Nas.

Berbeda halnya dengan susunan ayat al-Qur'an yang disepakati sebagai tauqifiy nabi, dalam persoalan susunan dan urutan surat al-Qur'an terdapat perbedaan pendapat ulama menjadi tiga pendapat sebagai berikut :

\section{Tertib surat-surat al-Qur'an selu-} ruhnya adalah ijtihadiy para shahabat. Pendapat ini dinisbahkan kepada Jumhur Ulama termasuk Imam Malik dan Qadhi Abu Bakar al-Baqilaniy dan Abu Husain Ahmad bin Faris. Pendapat ini didasarkan kepada beberapa alasan :

a. Adanya keberagaman tertib surat pada mushaf-mushaf para shahabat, sebelum masa kodifikasi.

- Ubay bin Ka'ab menyusun tertib mushafnya diawali dengan surat al-Fatihah, alBaqarah kemudian an-Nisak, Ali Imran kemudian alAn'am.

- Ibnu MAs'ud menyusun mushafnya diawali dengan surat al-Baqarah, an-Nisak, Ali Imran.

- Ali menyusun tertib mushafnya berdasarkan turunnya wahyu yang dimulai dengan surat al-'Alaq, al-Mudatsir, Qaf, al-Muzammil. (AzZarqaniy : 353)

Berdasarkan perbedaan tertib mushaf para shahabat inilah muncul pemahaman bahwa seandainya tertib mushaf tersebut adalah tauqifiy tentu para shahabat tidak akan berbeda dalam penulisan tertib mushaf mereka.

b. Adanya riwayat dari Ibnu Abbas :

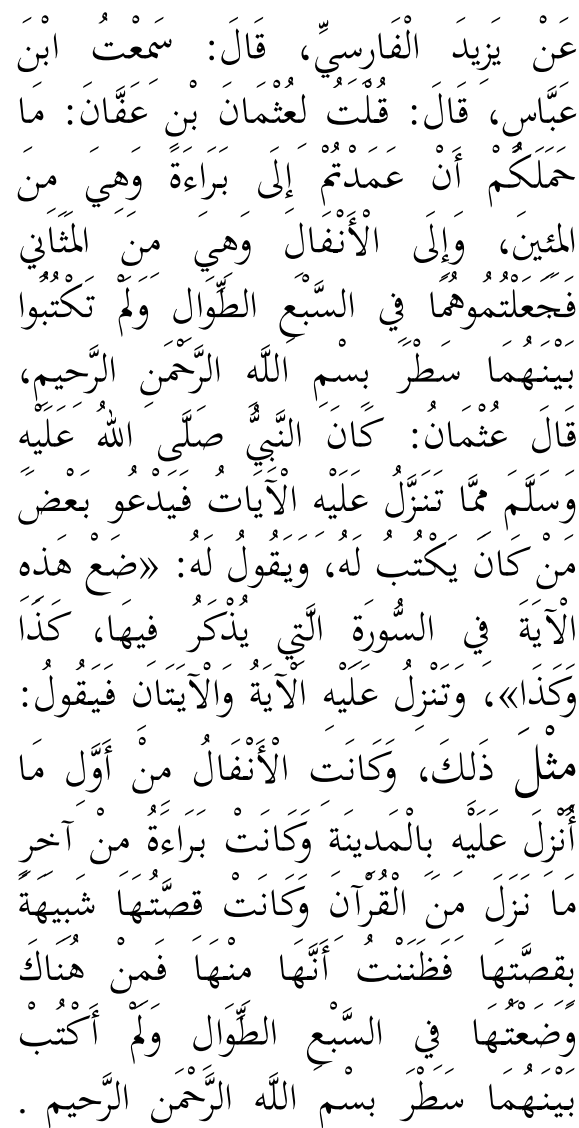

(Kútubuttis'ah' : Ábú daud : no. 786).

Dari Yazid al-Farisi ia berkata : Aku mendengar Ibnu Abbas berkata : Aku bertanya kepada Usman bin Affan :" Apakah yang menjadi alasanmu meletakkan surat Baraah yang termasuk kategori al-miin dan surat alAnfal yang merupakan almatsani, engkau tempatkan keduanya pada sab'u ath-thiwal dan tidak engkau tuliskan bismillahirahmanirrahim antara 
190 JURNAL ULUNNUHA, Volume 6, Nomor 2, Desember 2017, hlm.185-196

keduanya. Usman menjawab : Adalah Nabi Saw ketika turun beberapa ayat, beliau memanggil beberapa penulis wahyu dan berkata kepadanya: "Letakkan ayat ini pada surat yang menyebutkan di dalamnya tentang ini dan ini. Ketika turun satu atau dua ayat maka beliau akan memerintahkan seperti demikian. Surat al-Anfal termasuk surat yang pertama yang diturunkan di Madinah dan surat Baraah termasuk surat terakhir yang diturunkan. Kisah pada surat alAnfal mirip dengan kisah pada surat Baraah, sehingga aku mengira bahwa surat Baraah adalah bagian dari surat alAnfal, karena itu aku letakkan pada as-sab'u ath-thiwal dan tidak aku tuliskan antara keduanya bismillahirrahmanirrahim.

Riwayat tersebut menjelaskan bahwa tertib surat Baraah dan al-Anfal dituliskan berdasarkan ijtihad dari Usman, hal ini menggambarkan bahwa usman telah berijtihad untuk menentukan tertib dalam mushhaf.

\section{Tertib Mushaf seluruhnya adalah} tauqifiy dari Nabi, sebagaimana tauqifiynya tertib ayat. Pendapat ini dinisbahkan kepada Abu Bakar alAnbari, Abu Ja'far an-Nuhas dan atThibiy. Pendapat ini berdasarkan kepada alasan :

a. Surat-surat yang mirip isinya tidak diletakkan berurutan dalam mushaf, namun diletakkan terpisah, seperti surat-surat yang dibuka dengan musabbihat (ayatayat yang dimulai dengan tasbih kepada Allah) tidak diletakkan secara berurutan tapi diselingi dengan surat lain. Sebagaimana surat at-Taghabun dengan surat al-Jumu'ah yang diselingi oleh surat al-Munafiqun. Demikian pula surat al-Hasyar dan as-Shafat yang diselingi oleh surat alMumtahanah. Jika tertib surat adalah ijtihad tentunya ayat-ayat yang senada akan diletakkan berdekatan bukannya terpisah seperti pada susunan mushaf yang ada sekarang.

b. Tidak seorang pun shahabat yang keberatan dengan tertib surat yang disusun oleh USman, kesepakatan tersebut tidak akan terwujud bila tertib surat bukan tauqifiy. Bahakan mereka bersedia melepaskan mushaf mereka masing-masing. (azZarqaniy : 354-355)

c. Melihat kepada riwayat-riwayat yang menjelaskan bahwa Rasulullah telah membaca beberapa surat secara berurutan dalam shalat, diantaranya riwayat dari Ibnu Abi Syaibah yang menyatakan bahwa nabi pernah membaca beberapa surat mufasshal dalam satu rakaat. (Manna' Khalil al-Qathan : 141)

3. Susunan surat-surat al-Qur'an sebagiannya tauqifiy dan sebagian lagi ijtihadiy. Pendapat ini didasarkan kepada riwayat-riwayat yang menerangkan tentang tauqifiynya beberapa surat antara lain : 


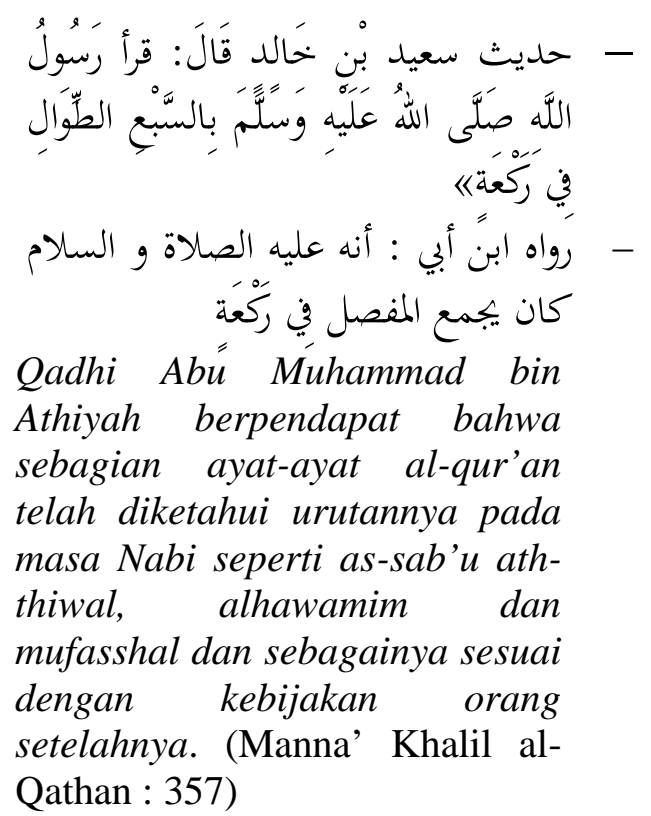

Dari ketiga pendapat tentang tertib surat-surat dalam al-Qur'an, terlihat bahwa masing-masing kelompok memiliki argumen dan alasan. Namun pendapat yang kedua dipandang dapat dijadikan hujjah dibandingkan 2 pendapat yang lain. Di samping argument yang dikemukakan oleh kelompok kedua di atas, ada beberapa alasan lain yang mendukung pendapat tersebut dan sekaligus menunjukkan kelemahan dari argumen kelompok pertama dan ketiga.

Para shahabat memiliki masingmasing mushaf pribadi yang saling berbeda dalam tertib suratnya, hal ini belum bisa dijadikan dalil bahwa tertib mushaf adalah ijtihadiy.

Berbedanya tertib surat pada mushaf para shalabat dapat diakibatkan dari faktor belum turunnya al-Qur'an secara lengkap sehingga para shahabat menuliskan mushaf sesuai dengan informasi yang mereka terima dan tertib yang telah mereka dengar dari Rasul.
Selain itu mereka menuliskan tertib surat al-Qur'an hanya untuk kepentingan pribadi untuk memudahkan mereka dalam menghafalnya. Oleh karena tertib surat bukanlah ijtihad masing-masing shahabat, maka para shahabat sepakat menerima dan berpegang dengan tertib mushhaf yang disusun oleh Usman dan Timnya, bahkan mereka bersedia meninggalkan tertib mushaf mereka masing-masing dan rela membakarnya karena tertib surat merupakan tauqifiy dari Rasul.

Selain itu riwayat dari Ibnu Abbas yang dipakai oleh kelompok pertama, merupakan hadis gharib ${ }^{2}$. Yang hanya ditemukan pada jalur riwayat dari 'Auf dari Yazid al-Farisi dari Ibnu Abbas. Berdasarkan penelitian, ternyata terdapat cacat pada sanadnya, dimana Yazid al-Farisi dinilai sebagai rawi Majhul $^{3}$. Kualitas rawinya tersebut menempatkan riwayat ibnu Abbas ini menjadi tertolak dan tidak bias dijadikan hujjah untuk menetapkan bahwa tertib surat adalah ijtihadiy.

Pada dalil lain yang digunakan oleh kelompok ketiga, sama sekali tidak dapat dipahami sebagai landasan yang menunjukkan bahwa sebagian durat adalah tauqifiy dan sebagian lainnya adalah ijtihadiy, bahkan dalil-dalil yang dikemukakan tersebut menunjukkan bahwa tertib/susunan surat berasal dari Rasul (tauqifiy).

${ }^{22}$ Hadis Gharib : Hadis yang diriwayatkan hanya dari satu jalur periwayatan pada setiap thabaqat atau sebagian thabaqat

${ }^{3}$ Rawi Majhul : Rawi hadis yang tidak diketahui identitasnya, sehingga jalur riwayat yang terdapat rawi majhul, dinilai sebagai jalur yang tidak muttashil. 
192 JURNAL ULUNNUHA, Volume 6, Nomor 2, Desember 2017, hlm.185-196

Indikasi lain yang menjelaskan bahwa susunan surat adalah tauqifiy adalah pernyataan al-Kirmaniy, sebagaimana dikutip oleh as-Suyhuthi, bahwa susunan dan urutan ayat al-Qur'an sebagaimana susunan yang sekarang berdasarkan kepada susunan surat alQur'an yang terdapat di Lauh Mahfuz. (as-Suyuthi : 64-65) berdasarkan hal ini pula Nabi membacakan di hadapan Jibril A.S. setiap tahun, dan pada tahun terakhir kehidupannya, Nabi sempat membacanya dua kali.

\section{RASM AL-QUR'AN}

Rasm secara etimologi dapat berarti : الأثر (bekas), التمثيل (perumpamaan), mendeskripsikan sesuatu dengan pena atau tulisan bergambar, النقس lukisan/ukiran)

Abdul Fatih Ismail Tsa'labi menjelaskan bahwa rasm secara bahasa adalah :

الرسم أصله الأثر الكتابة وهو تصوير الكلمة بحروف هجائها بتقدير الإبتداء بها والوقوف عليها (Abdul faith Ismail Tsa'labi, t.th : 9)

Rasm berasal dari “atsar”, maksudnta corak penulisan terhadap ucapan dengan huruf hijaiyah dengan menentukan ibtida' dan waqaf.

Bila dihubungkan dengan alQur'an, maka rasm al-Qur'an berarti bentuk-bentuk penulisan terhadap bacaan al-Qur'an. Yang secara terminology dikemukakan oleh Manna' Khalil alQathan :

طريقة خاصة في الكتابة ارتضاها لهم عثمان (Manna' Khalil al-Qathan : 146)
Metode Khusus pada penulisan kitab yang disetujui oleh Usman.

Sedangkan az-Zarqaniy menjelaskan bahwa yang dimaksud dengan rasm al-Qur'an atau rasm mushaf adalah رسم المصحف يراد به الوضع الذى ارتضاه عثمان

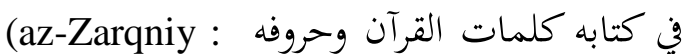
369)

Dapat dipahami bahwa yang dimaksud dengan rasm al-Qur'an adalah penulisan al-Qur'an dengan berpedoman kepada kaidah-kaidah kebahasaan seperti : hazaf, ziyadah, badal, washal dan fashal sebagaimana yang kita temui pada tulisan al-Qur'an yang ada sekarang.

Pada sejarahnya, penulisan dan pengeditan al-Qur'an dari segi tulisan dan dialektika dilakukan oleh empat orang shahabat yang diketuai oleh Zaid bin Tsabit di bawah pengawasan Usman bin Affan. Mushaf ini kemudian dikenal dengan nama mushaf Usmaniy. Penulisan al-Qur'an tersebut mengikuti kaidahkaidah khusus yang telah disebutkan di atas.

Setelah rampungnya penulisan ulang al-Qur'an tersebut, muncul pertanyaan di kalangan umat Islam tentang statusnya apakah tauqifiy atau isthilahiy, yang kenudian sangat erat hubungannya dengan hukum mengikuti pola penulisan dari rasm tersebut.

Terdapat tiga pendapat tentang persoalan rasm ini :

1. Jumhur ulama, diantaranya Ibnu Mubarak mengutip pendapat gurunya Abdul Aziz ad-Dabbagh, bahwa rasm al-qur'an adalah tauqifiy. Pola 
penulisannya bukan berasal dari ijtihad para shahabat, sebab penulisan al-Qur'an telah ada semenjak zaman Rasulullah dan tidak mengkun mereka sepakat dalam hal yang bertentangan dengan kehendak Rasulullah, sehingga wajib mengikuti pola penulisan rasm al-Qur'an. (azZarqaniy : 377-378)

Pendapat ini, mengutip satu riwayat sebagai pendukungnya, yang menjelaskan bahwa nabi meletakkan undang-undang penulisan wahyu seperti perkataan beliau kepada Muawiyah sebagai salah seorang penulis wahyu :

$$
\begin{aligned}
& \text { "ألق الدواة وحرف القلم وأنصب الباء وفرق } \\
& \text { السين ولا تعور الميم وحسن الله ومد الرحمن }
\end{aligned}
$$

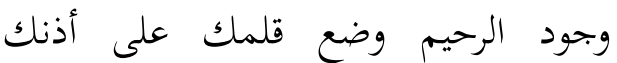

$$
\begin{aligned}
& \text { اليسرى فإنه أذكر لكود وضع }
\end{aligned}
$$

Letakkan wadah tinta, miringkan pena, luruskan ba, renggangkan sin, jangan butakan (tanpa lubang) mim, perbaikilah tulisan Allah, panjangkan ar-Rahman, baguskan ar-Rahim, dan letakkan penamu di atas telinga kirimu, karena akan lebih mengingatkanmu.

Argumen lain yang digu-nakan sebagai penguat pendapat ini adalah penambahan dan pengu-rangan huruf dalam penulisan ayat al-Qur'an, seperti lafaz سعو pada surat an-Naba' dan penambahan huruf pada سعو pada surat al-Hajj, penulisan seperti itu memiliki rahasia yang tersembunyi, jadi tidak mungkin ditulis tanpa ketetapan dari Rasul.(Subhi al-Shalih, 1985 : 276)
Maka menurut pendukung pendapat ini, penulisan mushaf pun harus sesuai atau mengikuti bentuk penulisan pada rasm al-Qur'an, karena terjadinya ijma' atas rasm Usman tersebut menunjukkan tidka boleh beralih kepada yang lain.

2. Sebagian Ulama berpendapat bahwa rasm al-qur'an bukan tauqifiy dari Nabi, tetapi suatu istilah yang disepakati oleh usman dan diterima baik oleh umat Islam, sehingga dari kesepakatan tersebut wajib mengikuti penulisan rasm Usman dan tidak boleh menyalahinya. Di antara ulama yang mendukung pendapat ini adalah Imam Malik, beliau pernah ditanya apakah boleh menulis al-Qur'an dengan kaidah hijaiyah, maka Malik menjawab tidak kecuali menurut tata cara penulisan pertama, (Subhi asShaleh : 276) yaitu rasm al-Qur'an.

3. Sekelompok ulama berpendapat bahwa rasm al-Qur'an hanyalah istilahi dan tidak terlarang menyalahinya. Di antara ulama yang mendukung pendapat ini adalah Ibn Khaldun dna Qadhi Abu Bakar. Pendapat ini berlandaskan kepada argumen bahwa di dalam al-Qur'an ataupun mafhumnya tidak pernah ditemukan penjelasan yang mewajibkan penulisan rasm alQur'an dengan rasm tertentu, dan tidak juga ditemukan adanya perintah meninggalkan rasm tertentu, begitu pula dalam sunnah dan qiyas-qiyas syar'i. bahkan sunnah sendiri memperbolehkan menggunakan rasm mana saja yang mudah, karena rasul memerintahkan menulis tanpa menjelaskan jenis rasm yang 
194 JURNAL ULUNNUHA, Volume 6, Nomor 2, Desember 2017, hlm.185-196

digunakan. Oleh sebab itu tidak ada keharusan mengikuti penulisan rasm Usman karena rasm hanya sekedar symbol atau isyarat. (az-Zarqaniy : 380-381)

Dalam menyikapi perbedaan pendapat tersebut, penulis sependapat dengan Subhi as-Shalih yang menyatakan bahwa keutamaan berpegang pada rasm al-Qur'an adalah suatu masalah yang secara mendasar berbeda dengan pendapat yang memandang pola penulisan al-Qur'an tauqifiy atau ishthilahiy. (Subhi-as-Shalih : 278) hal tersebut adalah 2 persoalan berbeda, sehingga pendapat kedua dan ketiga terlihat sejalan dalam hal rasm al-Qur'an adalah ishthilahiy, dalam arti istilah yang dipakai pada pola penulisan yang dilaksanakan oleh Usman dan timnya.

Hanya saja kedua pendapat tersebut berbeda dalam hal menentukan hokum mengikuti penulisan dengan rasm al_Qur'an yang ditetapkan Usman. Maka dalam pola penulisan (rasm) al-Qur'an, penulis lebih sependapat dengan pendapat yang menyatakan bahwa rasm al-Qur'an bukanlah tauqifiy, namun hanya merupakan istilah yang digunakan pada pola penulisan yang ditetapkan oleh Usman dan tim penyusunan mushaf, dengan alasan bahwa apabila rasm alQur'an tauqifiy tentunya akan ditemukan informasinya secara mutawatir, sesuai dengan mutawatirnya al-Qur'an, karena setiap kali al-Qur'an turun, nabi selalu memerintahkan para sekretarisnya untuk menuliskannya dan menjelaskan langsung hal-hal yang terkait dengan ayat yang diturunkan, seperti letak/ posisinya dalam suatu surat.
Pada kenyataannya informasi tentang rasm tidak pernah ditemukan, walau pun pendapat pertama berdalil dengan riwayat dari Mu'awiyah tentang penetapan bentuk-bentuk huruf, namun tidak dapat dipahami sebagai tauqifnya rasm al-Qur'an, sebab riwayat tersebut hanya menjelaskan bentuk-bentuk penulisan terhadap huruf dan kalimat tertentu bukan menunjukkan pola atau kaidah penulisan terhadap rasm alQur'an seperti : hazf, badal, ziyadah dan lainnya.

Di samping itu, seandainya rasm al-Qur' an adalah tauqifiy, tentunya istilah yang dipakai adalah rasm nabawy bukan rasm usmaniy, hal ini dipertegas lagi dengan keterangan yang menyatakan bahwa pada saat terjadi perbedaan antara Zaid bin Tsabit dengan anggota tim lainnya (yang seluruhnya adalah orang Quraisy) pada lafaz التابوة dan التابوت, maka Usman memerintahkan untuk mengikuti penulisan menurut bahasa Quraisy maka dipilihlah lafaz التابوت.

Sedangkan dalam hukum mengikuti penulisan rasm Usman, penulis berpendapat bahwa hal tersebut tidak wajib, karena tidak ada dalil yang menunjukkan wajibnya penulisan mushaf dengan rasm Usman atau pun lainnya. Tetapi rasm Usman tetap harus dijadikan standarisasi dalam pola penulisan alQur'an.

\section{PENUTUP}

Para ulama sepakat menyatakan bahwa susunan ayat-ayat al-Qur'an merupakan hal yang bersifat tauqifiy, yaitu berdsarkan petunjuk dari Nabi Muhammad Saw. 
Berbeda dengan hal tersebut, dapat perbedaan pendapat. Ada yang dalah hal tertib dan susunan surat ter- menilai rasm al-Qur'an adalah tauqifiy dapat perbedaan pendapat para ulama, dan ada yang menilai bukan tauqifiy tapi ada yang berpendapat tertib surat tau- hanya istilah yang disetujui oleh Usman qifiy ada yang berpendapat ijtihadiy dalam menetapkan pola penulisan albahkan ada yang berpendapat sebagian Qur'an. Berdasarkan argumen yang tauqifiy sebagian ijtihadiy. Dalam hal ini dikemukakan dapat disimpulkan bahwa pendapat yang menyatakan tertib surat rasm Usman bukan tauqify namun hanya adalah tauqifiy memiliki argumen yang sitilah yang disepakati oleh Usman yang lebih kuat dibandingkan dua pendapat tidak wajib mengikuti pola penulisan lainnya.

Sedangkan dalam menyikapi permasalahan rasm al-Qur'an juga terrasm Usman, namun tetap harus dijadikan standarisai pola penulisan alQur'an.

\section{REFERENSI}

AF, HAsanuddin, Perbedaan Qira'at dan Pengaruhnya terhadap Istinbath Hukum dalam alQur'an, Jakarta : PT. Raja Grafindo Persada, 1995

Farjani, Muhammad Rajab, Kaifa Nataaddab ma'a al-Mushaf, t.tp : Dar al-I'tisham, 1978

Al-Qathan, Manna' Khalil, Mabahits fi 'ulum al-Qur'an, Beirut : Muassasah al-Risalah, 1983

As-Shalih, Subhi, Mabahits fi 'Ulum alQur'an, Beirut : Libanon, dar al-'Ilmi, 1985

Shihab, Quraish, Mukjizat al-Qur'an,

As-Suyuthi, Jalaluddin, al-Itqan fi 'Ulum al-Qur'an, Libanon : Dar alFikr, 1979

Tsa'labi, Abdul Fatih Ismail, Rasm alMushaf wa al-Ihtijaj fi alQiraat, Mesir : Maktabah alNahdah, t.th.

Al-Yasu'i, Abu Luwis Ma'luf, al-Munjid fi al-Lughah wa al-A'lam, Beirut : Dar al-Masyriq, 1986

Az-Zarqaniy, Muhammad Abdul 'Adzim, Manahil al-'Irfan fi 'Ulum al-Qur'an. Juz .I, Beirut : Dar al-Kutub al-'Ilmiyah, 1990 Jakarta : Mizan, 1998 